\title{
Pengembangan Materi Ajar Bahasa Inggris Berbasis Project Based Learning untuk Siswa Jurusan Usaha Perjalanan Wisata
}

\author{
${ }^{1}$ Istina Atul Makrifah, ${ }^{2}$ Widiarini \\ 1,2Program Studi Pendidikan Bahasa Inggris \\ Universitas Nahdlatul Ulama Blitar, Indonesia
}

Email: ${ }^{1}$ istina.atulmakrifah@gmail.com, ${ }^{2}$ widiarini@unublitar.ac.id

Tersedia Online di
http://www.jurnal.unublitar.ac.id/
index.php/briliant

Sejarah Artikel

Diterima pada 27 Agustus 2019

Disetujui pada 29 Agustus 2019

Dipublikasikan pada 31 Agustus 2019 Hal. 388-393

\section{Kata Kunci: \\ Pengembangan, materi ajar, Project based Learning, Usaha Perjalanan Wisata}

\section{DOI:}

http://dx.doi.org/10.28926/briliant .v3i4.357

Blitar, food dan handicraft. Keabsahan materi diperoleh dari observasi lapangan yang dilakukan peneliti dan kemudian disinkronkan dengan kurikulum yang digunakan. Dengan penekanan materi ajar Bahasa Inggris berbasis Project based Learning, siswa Jurusan Usaha Perjalanan Wisata dapat secara aktif dan kreatif mengembangkan kompetensi khusus dan membantu meningkatkan kemampuan Bahasa Inggris secara aktif.

\section{PENDAHULUAN}

Ketersediaan buku ajar yang baik dan relevan merupakan salah satu faktor yang menunjang keberhasilan proses pembelajaran di kelas. Hal ini dikarenakan buku ajar merupakan sumber belajar dalam memperoleh informasi dan mengembangkan ilmu. Sehingga, sudah seharusnya sebuah buku ajar mampu merefleksikan tujuan pembelajaran dan kompetensi siswa. Bagian utama dari buku ajar adalah isi yang merupakan bagian materi ajar yang digunakan dalam pembelajaran.

Pada kenyataannya, materi ajar Bahasa Inggris yang digunakan masih bersifat umum untuk SMA maupun SMK yang dapat dipakai oleh semua jurusan. Sedangkan pada setiap jurusan di sekolah memiliki tujuan pembelajaran khusus yang diharapkan dalam penggunaan Bahasa Inggris. Khusus untuk SMK, materi ajar Bahasa Inggris yang sesuai dengan masing-masing kompetensi jurusan masih 
belum ada. Salah satu contohnya yaitu pada jurusan Usaha Perjalanan Wisata yang mana sangat erat kaitannya dengan kompetensi lulusan yang harus mampu menggunakana Bahasa Inggris sebagai bahasa asing dan bahasa internasional untuk memperlancar komunikasi baik lisan maupun tulisan. Sejalan dengan hal tersebut, menurut Dubicka, I. dan O'Keeffe, M. (2015) kemampuan berbahasa Inggris sangat diperlukan ketika mereka bekerja di industri pariwisata.

Pada tahap analisis awal, belum ada materi Bahasa Inggris yang dikembangkan sesuai dengan karakteristik dan kebutuhan siswa sesuai dengan yang diharapkan oleh silabus yang dapat membangun terjadinya pembelajaran yang bermakna. Materi yang diajarkan tidak berhubungan dengan kompetensi siswa di jurusan Usaha Perjalanan Wisata secara khusus dalam mengelola bisnis kepariwisataan dan tour guide dalam hal ini tentang Bahasa Inggris yang digunakan untuk mengelola usaha wisata yang mengangkat kearifan lokal di Kota dan Kabupaten Blitar. Dengan tema kearifan lokal yang ada di Kota dan Kabupaten Blitar ini juga merupakan upaya dalam mendukung program Pemerintah dalam memajukan sektor pariwisata terutama di Kota dan Kabupaten Blitar. Buku ajar yang bersifat khusus sesuai kompetensi jurusan akan membantu dalam mengembangkan kompetensi siswa terutama dalam penguasaan Bahasa Inggris.

Upaya pemecahan masalah tersebut adalah pembuatan materi ajar Bahasa Inggris untuk SMK jurusan Usaha Perjalanan Wisata untuk kelas $\mathrm{X}$ berbasis Project based Learning yang layak dari segi isi, bahasa, penyajian dan kurikulum. Bender, W. N. (2012) berpendapat bahwa Project based Learning adalah salah satu cara pembelajaran yang efektif dengan mengikutsertakan siswa membuat suatu proyek. Keikutsertaan siswa dalam melaksanakan proyek akan memberikan kesempatan bagi siswa untuk menemukan ide-ide baru bersama tim guna menghasilkan suatu produk. Materi ajar Bahasa Inggris yang akan dibuat berbasis Project based dengan harapan siswa mampu belajar secara mandiri dan aktif dalam mengembangkan ketrampilan berbahasa inggris dengan menghasilkan produk nyata dari hasil pembelajaran. hal ini didukung dengan pendapat Hanafiah dan Suhana (2009) yang mengatakan model pembelajaran ini melibatkan siswa untuk belajar secara mandiri dalam mengkunstruksi pembelajarannya dan mengaplikasikannya dalam produk nyata. Selain itu, siswa dituntut kreatif dan inovatif dalam menghasilkan produk sehingga ketrampilan Bahasa Inggris juga menjadi faktor penunjang keberhasilan.

\section{METODE}

Penelitian ini menggunakan pendekatan A Recursive, Reflctive, Design and Development (R2D2) yang dikembangkan oleh Willis (1995). Menurut Willis (1995) model R2D2 memiliki 3 prinsip yang fleksibel yaitu recursif, reflektif, dan partisipatoris. Pada tahap pertama recursif, suatu gagasan secara terus menerus dikaji selama proses perancangan dan pengembangan yaitu dengan pengumpulan data awal. Tahap kedua reflektif yaitu perenungan terhadap hasil analisis awal yang diperoleh. Data yang didapar dapat dipilah-pilah sesuai dengan kebutuhan dan situasi. Tahap ketiga yaitu participatory design yang mana tahap ini merupakan pendefinisian yang dilakukan oleh tim untuk menentukan keputusan atau kesimpulan yang disepakati terutama oleh guru sebagai pengguna materi dan terutama siswa sebagai subjek yang berhubungan langsung dengan materi 
tersebut. Data diperoleh dari hasil analisis awal materi yang terdapat pada buku ajar Bahasa Inggris yang dipakai, menganalisis kajian pustaka, wawancara tidak terstruktur kepada guru dan siswa,observasi lapangan ke beberapa tempat wisata yang ada di Kota dan Kabupaten Blitar. Analisis data dilakukan melalui teknik analisis interaktif dengan tahapan meliputi: (1) pengumpulan data, (2) pemilahan data, (3) pemaparan data, dan (4) mengambil kesimpulan.

\section{HASIL}

Kegiatan pendahuluan dilakukan untuk mendapatkan data awal. Langkah awal yang ditempuh adalah meminta ijin kepada sekolah yaitu SMK N 2 Blitar untuk melakukan penelitian. Sekolah tersebut dipilih karena memiliki Jurusan Usaha Perjalanan Wisata. Data-data awal tersebut dianalisis menggunakan metode deskriptif kualitatif untuk mengetahui gambaran materi ajar yang akan dikembangkan dan disesuaikan dengan silabus.

Analisis pada materi pada buku ajar Bahasa Inggris menunjukkan bahwa terdapat sebuah materi yang mengacu pada pariwisata disajikan dengan teks deskriprif membahas tentang ecotourism dan historical building, namun pariwisata yang diangkat masih secara luas, belum memuat pariwisata yang ada di Kota dan Kabupaten Blitar.

Selanjutnya, wawancara dilakukan kepada guru Bahasa Inggris selaku praktisi dan pengguna produk serta siswa sebagai sasaran produk. Dari hasil wawancara yang dilakukan kepada guru menunjukkan bahwa materi pada buku ajar Bahasa Inggris yang digunakan di sekolah masih bersifat umum dan belum berfokus pada kompetensi keahlian siswa terutama di Jurusan Usaha Perjalanan Wisata. Selain itu, materi Bahasa Inggris yang digunakan hanya mengacu dari pemerintah. Hal ini disebabkan belum adanya buku ajar Bahasa yang memuat materi sesuai dengan kebutuhan dan kompetensi keahlian siswa di Jurusan Usaha Perjalanan Wisata. Sejalan dengan hal tersebut, hasil analisis kejian pustaka yang dilakukan di toko buku seperti Gramedia, Togamas dan Restu menunjukkan belum ada materi buku Bahasa Inggris khusus untuk Jurusan Usaha Perjalanan Wisata berbasis Project Based Learning yang mengangkat kearifan lokal Kota dan Kabupaten Blitar. Buku- buku yang tersedia meliputi Bahasa Inggris untuk bisnis, English for food production, buku bahasa inggris untuk hukum dan lain sebagainya. Guru mengatakan bahwa mereka sangat membutuhkan materi yang sesuai sehingga dapat mengembangkan kemampuan bahasa Inggris siswa baik lisan maupun tulisan. Sedangkan hasil wawancara kepada siswa menunjukkan adanya kebutuhan materi yang sesuai dengan jurusan mereka. Sehingga diharapkan materi tersebut dapat meningkatkan kemampuan mereka untuk memakai bahasa inggris secara lisan maupun tulisan dalam mengelola bisnis kepariwisataan maupun tour guide.

Untuk menghasilkan materi ajar yang sesuai dengan kurikulum yang berlaku, peneliti melakukan analisis pada visi, misi, dan tujuan jurusan, silabus yang meliputi Kompetensi Inti (KI), Kompetensi Dasar (KD), tujuan pembelajaran, indikator, dan materi pokok. Pada setiap bab dipilah beberapa Kompetensi Dasar yang sesuai dengan pengembangan. Di kelas X terdapat 3 jenis teks yang diajarkan yaitu deskriptif, recount dan narrative. Materi ajar Bahasa Inggris khusus untuk jurusan Usaha Perjalanan Wisata ini akan memuat kearifan lokal pariwisata yang ada di Kota dan Kabupaten Blitar, sehingga peneliti

390 BRILIANT: Jurnal Riset dan Konseptual Volume 4 Nomor 3, Agustus 2019 
melakukan observasi lapangan untuk mendapatkan data nyata tentang objek wisata yang ditulis. Tempat-tempat yang dikunjungi meliputi Pusat Informasi Pariwisata dan Perdagangan (PIPP) kota Blitar untuk tema transportasi, 3 hotel di Kota Blitar untuk tema akomodasi, tempat wisata bahari, tempat wisata edukasi, tempat agrowisata, tempat wisata sejarah. Observasi lapangan juga bertujuan untuk mendapatkan foto/gambar autentik sehingga menghindari pelanggaran hak cipta. Materi lain yang ditulis adalah dasar-dasar Bahasa Inggris yang relevan dengan silabus.

\section{PEMBAHASAN}

Pengembangan materi ajar Bahasa Inggris berbasis Project Based Learning di fokuskan untuk siswa kelas X SMK Jurusan Usaha Perjalanan Wisata. Penelitian ini bertujuan untuk menghasilkan produk buku ajar Bahasa Inggris yang berisikan materi untuk mengembangkan kompetensi siswa Jurusan Usaha Perjalanan Wisata terutama dalam meningkatkan kepariwisataan dengan kearifan lokal di Kota dan Kabupaten Blitar.

Tahap awal penelitian adalah menganalisis buku ajar Bahasa Inggris yang dipakai dengan kesesuaian kurikulum. Tahap ini juga digunakan untuk melihat apakah buku yang digunakan sudah memenuhi kompetensi siswa. Wawancara juga dilakukan kepada guru dan siswa untuk mengetahui persepsi tentang materi ajar. Dari hasil wawancara yang dilakukan oleh guru diperoleh data bahwa materi dalam buku Bahasa Inggris yang digunakan bersifat umum yang dapat dipakai untuk SMA/SMK semua jurusan. khusus untuk buku tentang Bahasa Inggris yang menunjang kompetensi siswa Jurusan Usaha Perjalanan Wisata belum ada, sehingga guru berfokus pada materi di buku ajar utama. Hasil wawancara yang dilakukan kepada beberapa siswa secara acak menunjukkan materi pada buku Bahasa Inggris yang dipakai lebih menonjolkan pada kemampuan menulis dibanding kemampuan berbicara. Sesuai dengan tujuan utama pengajaran Bahasa Inggris di SMK adalah menyiapkan siswa untuk menguasai pengetahuan dan keterampilan bahasa inggris dasar yang akan mendukung pencapaian kompetensi ketrampilan program keahliannya dan untuk menerapkan penguasaan kemampuan dan ketrampilan bahasa inggris dalam komunikasi lisan dan tertulis pada tingkat lanjut (PerMenDiknas no. 22 tahun 2006), dapat disimpulkan bahwa siswa harus mampu menggunakan Bahasa Inggris tidak hanya pada kemampuan menulisnya tetapi juga pada kemampuan berbicara secara aktif untuk mendukung kompetensinya.

Selanjutnya dilakukan pengkajian bahan pustaka yang meliputi kajian teori pengembangan, teori pembelajaran berupa metode-metode pembelajaran yang sesuai dengan materi, realita buku-buku teks yang ada di toko-toko buku seperti Gramedia, Togamas, dan Restu dengan melihat materi ajar yang ada dan pemahaman tentang materi yang ideal.

Tahap penyusunan materi ajar Bahasa Inggris dilakukan dengan melihat hasil analisis awal dan wawancara guru dan siswa yang akan memiliki gambaran tentang materi ajar seperti apa yang harus disusun untuk menutup celah yang ada agar tujuan pembelajaran bahasa inggris dapat tercapai. Hal ini sesuai dengan Mashura (2003: 351) yang menyebutkan bahwa bahan ajar harus mampu menarik minat siswa dengan menyeleksi bahan yang cocok untuk pengajaran. Oleh sebab itu, peneliti memfokuskan pada kompetensi kejuruan pada Jurusan Usaha 
Perjalanan Wisata yaitu dengan materi kepariwisataan yang mengusung kearifan lokal Kota dan Kabupaten Blitar meliputi 4 jenis yaitu akomodasi dan transportasi, tempat pariwisata lokal di Kabupaten dan Kota Blitar, food dan handicraft. Materi ditunjang dengan ilustrasi gambar untuk memudahkan siswa mengenali objek materi. Setelah diperoleh gambaran tentang apa yang ditulis, selanjutnya peneliti merencanakan tujuan keseluruhan materi ajar dan menetapkan tujuan untuk masing-masing bab atau bagian. Dalam konteks penulisan materi ajar bahasa inggris untuk SMK, penyusunan materi menyesuaikan silabus Bahasa Inggris untuk kelas $\mathrm{X}$ dan semester dimana dalam setiap semester ada standar kompetensi dengan kompetensi dasar yang akan dicapai, lengkap dengan jenis teks yang harus dipelajari pada semester tersebut. Pada kelas X terdapat 3 jenis text yaitu deskriptif, recount dan narrative. Sehingga, buku akan disusun dengan menggunakan 3 jenis teks tersebut dengan tema yang berbeda.

Materi ajar Bahasa Inggris yang disusun berbasis Project based Learning dimana terdapat instruksi dalam buku untuk membuat siswa melakukan dan menghasilkan projek serta produk. Larmer et al., (2015) menyebutkan terdapat beberapa karakteristik pembelajaran Project based Learning, antara lain: (a) Proyek mengajarkan siswa tentang standar isi dalam suatu pembelajaran; (b) Tugas dalam menentukan proyek yang diberikan kepada siswa bersifat terbuka dan melibatkan suara pilihan siswa; (c) Siswa bekerjasama dalam tim untuk menyelesaikan proyek; (d) Proyek diselesaikan dengan bimbingan guru selama pelajaran berlangsung; (e) Pengerjaan proyek, meliputi proses penyelidikan berkelanjutan dan penciptaan suatu produk. Jurusan Usaha Perjalanan Wisata merupakan salah satu jurusan yang erat kaitannya dengan penggunaan bahasa asing untuk mengelola bisnis kepariwisataan maupun tour guide, sehingga Project Based Learning memberikan manfaat untuk melibatkan siswa secara aktif menggunakan Bahasa Inggris secara lisan maupun tulisan. Menurut NYC Department of Education (2009) model Pembelajaran Project based Learning merupakan model pembelajaran adar siswa membangun pengetahuan konten oleh mereka sendiri dan mendemonstrasikan pemahaman baru melalui berbagai bentuk representasi. Pada hasil penelitian sebelumnya yang dilakukan oleh Nurhajati dan Widiarini dengan judul Developing an Instructional Guideline using Project based Learning to Teach Speaking to Junior High School Students (2016) menunjukkan hasil bahwa banyak dari siswa senang mengerjakan proyek mereka yang berkolaborasi dengan graphic organizer untuk kemampuan speaking.

Sesuai dengan tingkatannya, materi juga berisi dasar-dasar berkomunikasi untuk tour guide dengan pemberian kosakata-kosakata bantu dan dialog sederhana. Beberapa percakapan yang disajikan dalam dialog seperti perkenalan dan perpisahan (greeting and leave taking), menanyakan informasi (asking information), menunjukkan tempat-tempat wisata (showing tourism object). Ketrampilan berbahasa meliputi 4 ketrampilan dasar yaitu, berbicara, mendengar, membaca dan menulis. Ketrampilan berbicara akan lebih ditonjolkan dengan melibatkan siswa pada kegiatan-kegiatan seperti berdialog dan proyek.

Observasi lapangan ke tempat wisata yang ada di Kota dan Kabupaten Blitar digunakan untuk menghasilkan teks yang otentik. Tempat wisata yang dikunjungi dibagi menjadi beberapa macam yaitu wisata sejarah seperti Candi Penataran dan Istana Gebang, wisata edukasi seperti Kampung Coklat dan Kebun Kopi Karanganyar, wisata bahari seperti Pantai Tambak, dan agrowisata seperti

392 BRILIANT: Jurnal Riset dan Konseptual Volume 4 Nomor 3, Agustus 2019 
Kampung Coklat. Selain tempat wisata, dilakukan pula observasi terhadap transportasi dan akomodasi berupa hotel di Kota Blitar. Sehingga buku yang dihasilkan juga dapat mengangkat kepariwisataan lokal untuk dikembangkan oleh siswa.

\section{KESIMPULAN}

Pengembangan materi ajar merupakan proses merancang kegiatan atau pengalaman belajar untuk tercapainya tujuan pembelajaran. Sehingga tujuan penelitian ini adalah menghasilkan materi ajar Bahasa Inggris yang berbasis Project based Learning untuk siswa SMK kelas X Jurusan Usaha Perjalanan Wisata untuk mencapai kompetensi khusus pada jurusan tersebut. Dari hasil kegiatan pendahuluan yang meliputi analisis awal materi yang terdapat pada buku ajar Bahasa Inggris yang dipakai, menganalisis kajian pustaka, wawancara tidak terstruktur kepada guru dan siswa, didapatkan data untuk selanjutnya dianalisis dan diolah menjadi materi ajar Bahasa Inggris yang sesuai dengan jurusan tersebut.

\section{SARAN}

Pengembangan materi ajar bahasa inggris untuk jurusan Usaha Perjalanan Wisata sangat perlu dilakukan untuk meningkatkan kompetensi siswa terutama dalam kecakapan berbahasa Inggris secara aktif untuk menghasilkan lulusan yang unggul.

\section{DAFTAR RUJUKAN}

Mashura, H. (2003). Materials for Developing Reading Skills. In B. Tomlinson (Ed). Developing Reading Materials for Language Teaching. London: Continuum.

Larmer et al., (2015). Setting the Standard for Project Based Learning: A Proven Approachto Rigorous Classroom Instruction. United States of America: ASCD Books andPublications.

Peraturan Menteri Pendidikan Nasional No. 22 Tahun 2006 tentang Standar Isi untuk Satuan Pendidikan Dasar dan Menengah. Jakarta: Depdiknas.

Dubicka, I. and O'Keeffe, M. (2015). English for International Tourism, Second Edition. London: Pearson Education ESL.

Hanafiah, Nanang dan Cucu, Suhana. (2009). Konsep Strategi Pembelajaran. Bandung: Refika Aditama.

NYC Department of Education. (2009). Project-based Learning: Inspiring Middle School Students to engage in Deep and Active Learning. New York.

Willis, J. dan Wright, K.e. 1995. A Recursive, Reflective Instructional Design Model based on Constructivist-interprivist Theory. Educational Technology.

Nurhajati, D., dan Widiarini. (2016). Developing an Instructional Guideline using Project based Learning to Teach Speaking to Junior High School Students. Proceeding of The $5^{\text {th }}$ ELTLT Conference. Semarang-Indonesia. 